AJSS, Vol. 6, No. 1, January - June 2007, pp. 9-11

ISSN 0975-329X| https://doi.org/10.12724/ajss.10.2

\title{
REFLECTED GLORY
}

\section{Swarnalatha lyer*}

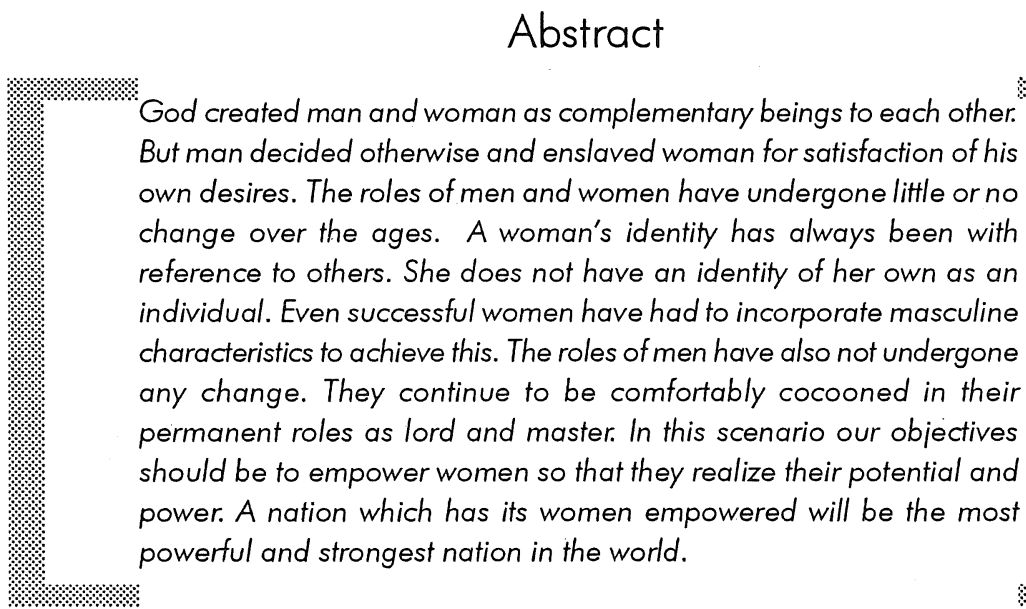

God created man and woman as complementary beings to each other. But man decided otherwise and enslaved women for satisfaction of his own desires. The role of men and women over centuries have undergone little or no change. If at all any change has taken place it is only an increase in responsibility for women. Women are good at multitasking; so they are increasingly being burdened with multiple responsibilities.

HOD, Dept. of Psychology (UG), Christ College, Bangalore

e-mail: swarnalatha.iyer@christcollege.edu 
According to an $\mathrm{HR}$ director "HR involves a lot of multitasking and juggling of different activities at the same time and women can do many things at the same time and are not thrown off by pressures." This statement has both positive and negative connotations. On one side it speaks about the super ability of women. On the other hand, this same ability is exploited by society-she is increasingly burdened with multiple responsibilities. Being a woman is like being on a stage enacting roles, being watched and often put to test. In a work scenario dominated by men, a woman has to prove that she is as good or even better than the men and at the same time fight stereotypes and biases. In the process a woman incorporates many a masculine characteristic because a working woman realizes it is better to have a "tough" image rather than a compliant one. A "successful" woman does not fit the feminine image : and confidence in a woman is termed as arrogance. To top it all, when a woman is immune to sexist manipulative tactics and is as efficient and capable as anybody else she is branded as "difficult". That is Kiran Bedi for you-the super-cop and superwoman.

A woman's identity has always been that of a wife, mother, daughter, mother-inlaw, daughter-in-law and so on..... always with reference to others. She does have an identity of her own as an individual. To this day the same sorry situation continues. The most powerful woman in India today-Mrs. Sonia Gandhi is referred to as "Desh ki bahu" (the nation's daughter-in-law) Ironical indeed.

In the 'MANU SMRITI' Manu lays down the rules for a married woman thus:-

KSHAMAYA DHARITRE

BHOJANESHU MATA

KARYESHU MANTRI

SHAYANESHU VESHYA.

(In tolerance she should be like the mother earth;

In serving she should be a mother;

In management she should be a minister;

In bed she should be a prostitute.)

All this has to be followed by a woman if she has to keep her husband happy! And God forbid if she fails, her conscience is always there to make her feel guilty.

Through the ages women in our country have been worshipped as Lakshmi, Saraswathi, Shakthi etc. But we have no qualms in suppressing them in more ways than one. The "Ghar ki Lakshmi" is beaten, bruised or burnt if she fails to bring a 
hefty dowry. In this land of Saraswathi Pooja, a girl is denied the right to education because the parents would find it difficult to get a more educated match for her- in marriage of course! A woman who earns as much or even more than her husband still has to account for her own money to her husband! But the man squanders away his money- no questions asked.

Discrimination against the female occurs throughout life- from the womb to the tomb Female foeticide, female infanticide, dowry deaths - all these are considered as social problems and we just raise a brow and move on. These problems do not enrage us any more. Recently 30 bags full of girl-baby parts were dug up from the premises of a hospital in Orissa. $75 \%$ of unexplained baby deaths happen to be girls. In the case of organ transplant, when a man needs a kidney or a liver it is the wife, sister, or mother who provides it. But very few women receive organs from male donors. The so called protectors (read men) hardly ever donate an organ to save the life of a woman they claim to protect!

In this scenario our objectives should be to empower women so that they realize their potential and power. Empowerment will not become a reality until attitudes toward women change. When women attain freedom from the shackles of bondage; when they are free to make their own decisions; when society gives them the respect due to them- then and only then can we have empowered women.

Unfortunately, the tools of empowerment have been used for disempowerment. Education, wealth and technological advances have become slaves to prejudice. Sex-selective abortions are most prevalent among the educated. Education has failed because there is no link between what we learn and what we believe.

The roles of men have also not undergone any change. They continue to be comfortably cocooned in their permanent roles as lord and master. The "ABHIJNANA SHAKUNTALAM" says, "Authority over a wife in every way is justifiable." Why would a man want to give up this kind of authority? When a woman takes care of all that has to be done, then what really does a man do? Enjoy a comfortable life, of course.

If you have noticed the recent trends in school and competitive exams, the merit lists are dominated by girls. But in the office situation they seem to have lost this advantage because for the first time they are evaluated not as another roll number but as a woman!! Many years ago Wall-Street Journal had coined the term "glass ceiling" to refer to the apparent barriers that prevent women from reaching the top. The only women who have made it to the top are those who chose their own path and were efficient professionals. 